\title{
Model for Population Zero
}

\author{
Xiao Man Luo ${ }^{1, a}$ \\ ${ }^{1}$ School of North China Electric Power University, Baoding 071000, China \\ a719481750@qq.com
}

\begin{abstract}
New technologies, including personalized artificial augmentations units, will soon enable humans to inhabit manufactured cities on Mars by 2100. The first wave of migration, called Population Zero, will include 10,000 people.Population Zero aims to have optimal conditions in many workforce and social living factors.In this problem, we have different aspects to consider. First step, we defined some parameters that connect to those three prior elements to calculate. Next we set some norms to judge whether the system could meet the requirement. Secondly, to fetch data we generated a sample population of 10,000 people to emigrate to Mars. To make the simulation more appropriate, the distribution of citizen in terms of factors were taken into consideration.
\end{abstract}

Keywords: Population Zero,the multiple linear regression prediction

\section{Introduction}

With the goal of creating an optimal workforce to give all people the greatest quality of life with a vision of sustainability for the next 100 years, scientists come up with this puzzle that how to design an economic-workforce-education system that they can implement with Population Zero. Moreover, we need to create the life there sustainable and stable. Therefore, this model should be applied to improve our life on earth.

\subsection{Model}

The established model is as the following figure:

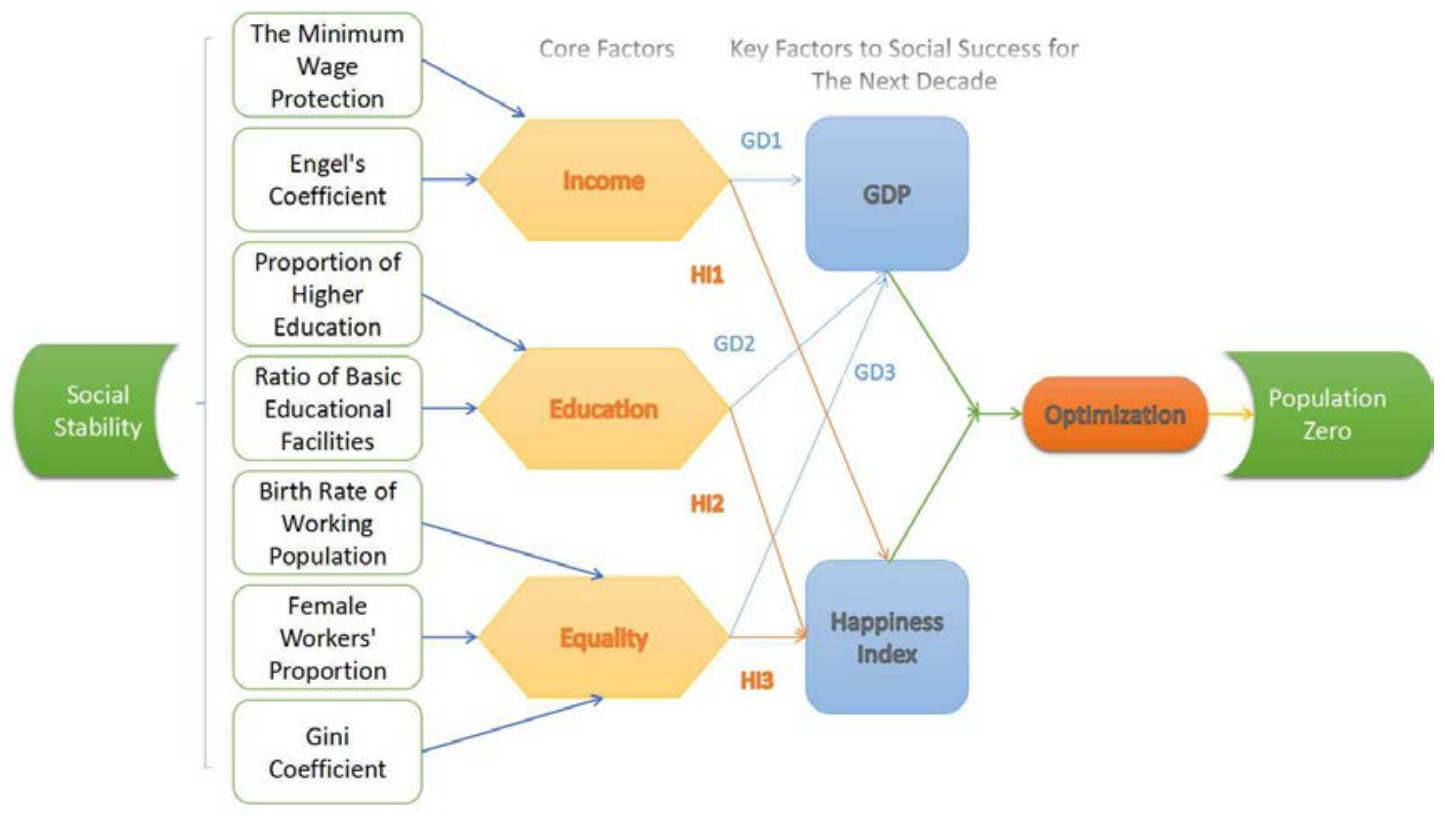

Figure 1 The Model

Inspired by PCA, we use the factors in Model 1 to analyze :

By means of MATLAB, we can get the table as following : 
Table 1 Different Factors’ Weight

\begin{tabular}{|c|c|c|c|}
\hline Core Factor & $\begin{array}{c}\text { Weight } \\
\text { (pi) }\end{array}$ & Sub-factors & Weight ( pj) \\
\hline \multirow{2}{*}{$\underline{\text { Income }}$} & \multirow{2}{*}{0.29} & Minimum Wage & 0.17 \\
\hline & & Engel's Coefficient & 0.12 \\
\hline \multirow[b]{2}{*}{ Education } & \multirow[b]{2}{*}{0.33} & Higher Education Ratio & 0.23 \\
\hline & & $\begin{array}{l}\text { Basic education facilities } \\
\text { containing rate }\end{array}$ & 0.12 \\
\hline \multirow{3}{*}{ Equality } & \multirow{3}{*}{0.36} & Birth Rate of Labor Force & 0.11 \\
\hline & & Women Working Rate & 0.09 \\
\hline & & Gini coefficient Level & 0.16 \\
\hline
\end{tabular}

Based on the parameters that we have defined in Task 1, we can integrate these three factors. For example, the critical interdependencies affect the social stability.

Also, there are additional constraints required to preserve the outcomes over the 10 year period. For example, we should pay much attention the population structure: it is of great importance to control the birth rate to avoid being plagued with overpopulation, moreover, for an efficient social division of labor, we should balance out the proportion of men and women in the population, which contributes to maintaining a good social order for a long period of time.

However, the model sample is a little bit small so that there may be some instability in it, in that case we should not only assess it regularly but also take proper measures to adjust it. Here what we should be concerned is the birth rate as well as the gender ratio. By judging that whether they still within limited scope in a certain period, we obtain the reasonable the time interval of model assessment.

We compared the professional workforce with the unskilled labor force, since the situations are different in each groups, the fuzzy analysis is used to sampling simulation.

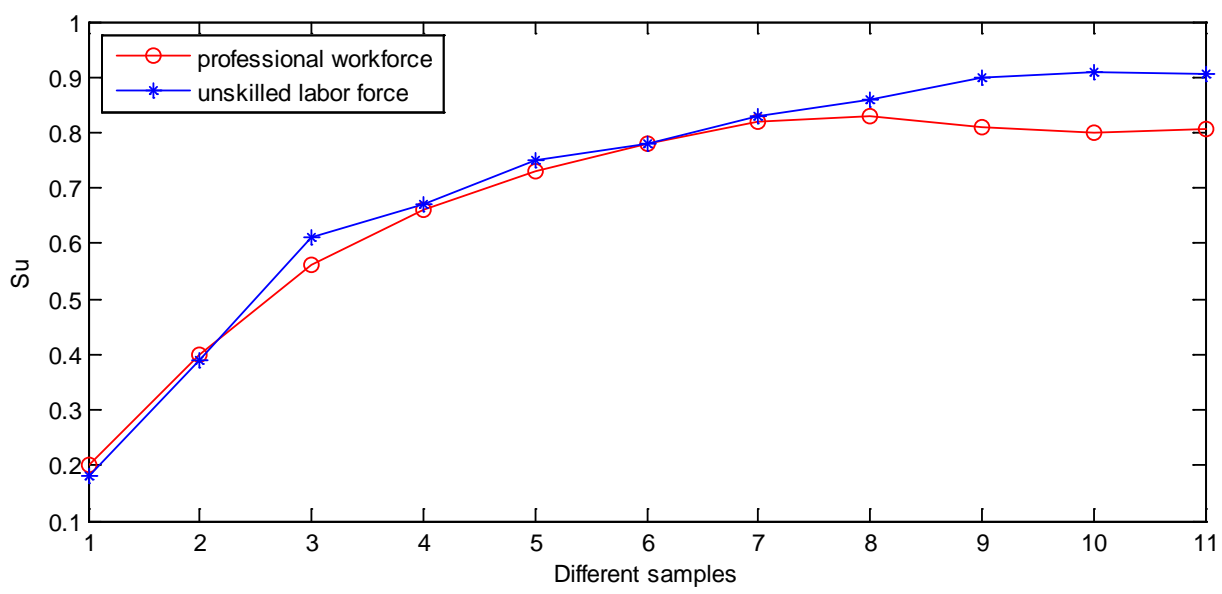

Figure2 Different Samples’ Substainable Base

(Instruction: In the sample, the income weight scope in the professional workforce and unskilled labor force are $0.30-0.40$ and $0.55-0.61$ respectively, and the income weight in increases gradually.)

After analyzing the table, we obtain: Though to professional workforce, income is not that important, however, it's the core factor to GDP, as a result, Su cannot increase incrementally with the increase of the income weight, finally the model may no longer produce optimal outcomes.

So we need to add some constraints to maximize the priority outcomes. And then we get the limited scope by redefining the weight factors table like this: 
Table 2 Different Samples’ Weight (Add limited elements)

\begin{tabular}{|c|c|c|c|c|c|c|}
\hline Different Groups & Income & $\mathbf{P i}$ & Education & $\mathbf{P i}$ & Equality & $\mathbf{P i}$ \\
\hline Professional & Wage & $0.37 \pm 6.7 \%$ & Training & $0.21 \pm 10.2 \%$ & Time Off & $0.22 \pm 9.3 \%$ \\
\hline Workforce & & & & & $\begin{array}{l}\text { Parental } \\
\text { Leave }\end{array}$ & $0.20 \pm 8.4 \%$ \\
\hline Unskilled labor & Minimum & $0.57 \pm 8.1 \%$ & & & Work Hours & $0.13 \pm 6.4 \%$ \\
\hline Force & Wage & & & & $\begin{array}{l}\text { Disability } \\
\text { Care }\end{array}$ & $0.14 \pm 9.7 \%$ \\
\hline Student & $\begin{array}{l}\text { Living } \\
\text { Expenses }\end{array}$ & $0.23 \pm 6.3 \%$ & Study & $0.52 \pm 10.1 \%$ & $\begin{array}{l}\text { Child Care } \\
\text { Graduation } \\
\text { Rate }\end{array}$ & $\begin{array}{l}0.16 \pm 7.3 \% \\
0.25 \pm 5.6 \%\end{array}$ \\
\hline $\begin{array}{l}\text { High School } \\
\text { Graduates }\end{array}$ & $\begin{array}{l}\text { Minimum } \\
\text { Wage }\end{array}$ & $0.52 \pm 7.1 \%$ & & & Work Hours & $0.48 \pm 9.6 \%$ \\
\hline $\begin{array}{l}\text { Under- } \\
\text { graduate }\end{array}$ & Wage & $0.38 \pm 8.2 \%$ & & & & \\
\hline $\begin{array}{l}\text { Master and } \\
\text { Doctors' graduates }\end{array}$ & Wage & $0.41 \pm 5.2 \%$ & $\begin{array}{l}\text { Further } \\
\text { Education }\end{array}$ & $0.32 \pm 6.3 \%$ & & $0.27 \pm 7.2 \%$ \\
\hline Believers & & & & & $\begin{array}{l}\text { Religious } \\
\text { Facilities } \\
\text { Diet }\end{array}$ & $\begin{array}{l}0.67 \pm 2.1 \% \\
0.33 \pm 3.2 \%\end{array}$ \\
\hline $\begin{array}{l}\text { Non-believers } \\
\text { Teenager }\end{array}$ & $\begin{array}{l}\text { Living } \\
\text { Expenses }\end{array}$ & $0.13 \pm 5.2 \%$ & Study & $0.87 \pm 9.6 \%$ & & \\
\hline Youth & $\begin{array}{l}\text { Living } \\
\text { Expenses }\end{array}$ & $0.24 \pm 6.3 \%$ & Study & $0.38 \pm 10.7 \%$ & $\begin{array}{l}\text { Graduation } \\
\text { Rate }\end{array}$ & $0.38 \pm 3.2 \%$ \\
\hline Mid-age and the & Wage & $0.22 \pm 7.1 \%$ & & & Work Hours & $0.18 \pm 5.6 \%$ \\
\hline Old & & & & & $\begin{array}{l}\text { Time Off } \\
\text { Child Care }\end{array}$ & $\begin{array}{l}0.22 \pm 3.5 \% \\
0.38 \pm 9.6 \%\end{array}$ \\
\hline
\end{tabular}

After limiting the model, the priority outcomes of the subgroups can be maximized without significantly reducing the global outcomes.

Compared with the 10-year-migration, a sample only including 10,000 people, the additional migration phased over the next 100-years is very different, since we have to take more migration factors into account, such as the available stock on Mars, saturation on the population intake capacity and employment owing to migration phased over the next 100-years and so on.

Moreover, in 10-year-migration, the Youth Population Proportion, Higher Education Population Proportion, the Professional Workforce Population Proportion are not sustainable in the next 100 the additional migration phased over the next 100-years since they are changeable, thus we add to some other migration factors to improve the model, in order to ensure our model continues to be effective for the entire 22nd century.

Strengths:

1. Our model forms comparatively perfect social and economic attribute as well as the spatiality of people migration, which cover all the concrete factors as possible

2. We establish the system used to evaluate the happiness index and sustainable society index measuring the social satisfaction after migrating to some extent.

3. We consider the available resources, employment saturation, share of resources, migration cost and so on, all of which would have an impact on the population and population structure of migration.

Weaknesses:

1. When it comes to the large population migration sample, some factors such as the youth population proportion, the higher education population proportion as well as the professional 
workforce are all different, which contribute to the changes of weight ratio of population structure making it difficult to describe the final results.

2. To the large population migration sample, it's difficult to collect the data since some small data sampling cannot be analyzed exactly by the statistic software. So to this kind of sampling, we have to take sample, as a result, the weight ratio cannot be determined more accurately

\section{Conclusions}

- Using the grey model and combined it with the multiple linear prediction which can help us get the multiple linear regression equation between factors and dependent variable.

- Creating the host country's effect which makes the factor more intuitive.

- Using SPSS to analysis the factors' influence which makes the result more persuasive.

- Divided the host country's effect into different levels to make the model more practical.

- The source data only refers to the result from 1980 to 2016, which sorrows the range of data.

- The model of the host country effect just divides the medals got in grade without exact number where may have more error.

\section{References}

[1] Coming to Play or Coming to Win:Participation and Success at the Olympic Games. Daniel K N Johnson,Ayfer Ali. . 2000

[2] Economic Incentives of the Olympic Games. Alexander Matros,Soiliou Daw Namoro. . 2004

[8] Eleonore Kofman, Gender and International Migration in Europe: Employment, Welfare, and Politics, 2000

[9] Alessandra Buonfinoa , Between unity and plurality: the politicization and securitization of the discourse of immigration in Europe, New Political Science, 2004, 26(1):23-49.

[10] Anthony H. Richmond, Reactive Migration: Sociological Perspectives On Refugee Movements, Journal of Refugee Studies,1993,6(1):7-24.

[11] Elizabeth Fussell, James R. Elliott, Introduction: Social Organization of Demographic

Responses to Disaster: Studying Population-Environment Interactions in the Case of Hurricane Katrina, Organization \& Environment,2014,22(4):379-394. 